\title{
The unclothed body on and off stage in the comedia nueva
}

\author{
Jonathan Thacker \\ University of Oxford
}

The heroine of Lope de Vega's early comedy, Los locos de Valencia, is on the run when the audience first sets eyes on her. Erífila has eloped with a servant, Leonato, to whom she has promised marriage in order to avoid an unappealing union arranged by her parents. ${ }^{1}$ Feigning offence when his mistress / lover describes her own dishonourable behaviour as mad, Leonato turns on her, steals her jewels and then forces her to undress and hand over her clothes too. If she was in a socially precarious position when she came on stage - having travelled far from home to arrive at the walls of the city of Valencia - her prospects have now become desperate. Erífila is alone, without possessions and unclothed: her social status is no longer indicated by her attire and she is thus vulnerable to disrespect or violence, to being misread, disbelieved and misunderstood by anyone she meets.

Erifila is one of many characters in the Golden Age comedia who appear on stage disrobed or unclothed. They are usually described as "desnudo" in the stage directions or play-text. Many other unclothed figures do not appear on stage but their nakedness is suggested or described, relayed to the audience by others, and is instrumental in the dramatic development of the piece, important to the playwright's intentions, and affects the spectators' pleasure in the play. In this study I aim to examine (a) what dramatic desnudez involved in practical terms on the stages of Golden Age commercial theatres, and (b) a range of examples of unclothed bodies, male and female, with the intention of asking what nakedness implied or represented in the minds of spectators and what feelings it aroused, whether it was depicted on or off stage. This is intended to be a survey which has a broader focus than some of the excellent 
studies (for example by Frederick de Armas, Esther Fernández Rodríguez and Maria Grazia Profeti) that have helped readers appreciate the eroticism which was an important part of the appeal of the comedia.

Desnudez in the corral

The reversal of fortune experienced by Erífila in act 1 of Los locos de Valencia demonstrates practically the way in which desnudez was depicted on the corral stage. When she enters at 1. 130, Lope's stage direction informs us that she is wearing "capotillo y sombrero", a short cape and hat that indicate to the audience that she has been travelling. ${ }^{2}$ Leonato robs her of these, "Deme el sombrero y capote" (1. 335), and proceeds to force her, at knife-point, to give him the rest of her fine clothing - "Quítese agora la ropa" (1.345), he says, and then "Y aun la camisa" (1. 346) - until she is, in her own words, left "desnuda" (1. 366). She refers twice more to her "desnudez" (1. 476 and 1. 516) when she is discovered hiding on the outskirts of Valencia by Pisano, the portero from its famous Hospital de los Inocentes, and some of the inmates from this asylum for the mentally ill.

Lope's stage directions - implicit and explicit - would have been conventionally understood by the autor de comedias and they make it clear what desnudo means in practice in the corral. The acotación after Leonato’s exit, reads “quede Erífila en un juboncillo, y un manteo" (at 1. 356). Erífila would have been as unclothed as it was permissible for an actress to be on stage in the period, which means she is wearing tight-fitting undergarments: the jubón, or juboncillo, is a doublet, "ceñido y ajustado al cuerpo" and the manteo is "cierta ropa interior ... que traen las mujeres de la cintura abajo, ajustada y solapada por delante". ${ }^{3}$ "Desnudo" - sometimes "medio desnudo" or "a medio vestir" - for male and female 
characters who appear on stage, does not imply nakedness, then, but indicates that the actor is most likely dressed in underclothes. The terms used to describe this and similar states of undress, as we shall see, can include wearing "ropa de levantar", appearing "en enaguas", and being "en cuerpo." This last (common) expression involves, according to Autoridades, a "modo de estar uno vestido con la vestidura precisa que ciñe el cuerpo: esto es, sin manto, capa u otras ropas de mayor adorno." 4

Thus, although the term desnudo was employed in general parlance and in the comedia to describe states from total nakedness to being partially clothed, its meaning when referring to a character on stage was clear. The outer clothes were removed to reveal the tighter-fitting underwear, meaning that the shape of the individual's body could be made out clearly by the audience. The character Claudio confirms as much when referring to the costume of one of his fellow masquers in act 3 of Lope's Las ferias de Madrid (1587?): "habéis querido que el buen talle, / la proporción y gracia de los miembros / se vea y juzgue en ese desnudillo" (ll. $2938-40) .^{5}$

In corral performances of Los locos de Valencia or any other play of the period, full nakedness would not have been permitted on stage, then, with only this state of déshabillé being allowed. Neither dramatic decorum nor contemporary morality allowed male or female actors to bare their bodies the way they might in a modern production of a Golden Age comedia. ${ }^{6}$ Indeed, moralists and churchmen frequently decried even this degree of undress on the stage and in the thespian world. In 1609, Juan de Mariana inveighed against the menace of scantily clad actresses performing in his condemnation of their very presence on stage: 
algunas veces en la misma representación se desnudan, o a lo menos, salen vestidas de vestiduras muy delgadas, con las cuales se figuran todos los miembros y casi se ponen delante de los ojos; pues ¿qué cosa hay más poderosa para enredar las almas y llevarlas a la muerte perpetua y inflamarlas que la vista de una mujer hermosa ataviada demás desto, provocando con meneos y palabras amorosas?

Nearly a century later, another Jesuit, Ignacio de Camargo, was still complaining about "la desnudez indecente de los trajes" worn by female actors. Visible cleavages confirmed for him that the theatres constituted the fount of all vices. ${ }^{7}$ The alluring female body, unclothed, expensively clothed, or presented in the form of the mujer vestida de hombre, ${ }^{8}$ was one of the elements of Golden Age theatre that produced institutional anxiety: its display was considered to have a pernicious effect on the minds and morals of the populace, prompting lascivious thoughts and even encouraging sinful actions.

Returning to Lope's stranded and unclothed Erífila, we see that she is not exaggerating in describing her state as one of desnudez. In her case, as already hinted (and as for many others), losing her clothes means losing her status, her social role. "Suele ser el vestido muda definición de su dueño," wrote Álvaro Núñez de Castro, in his Libro histórico político published in Madrid in 1658, and so, unattired, Erífila has lost her "carné de identidad, la carta de presentación del individuo, inserto en una sociedad cuyos estamentos mostraban la diferencia a través de estas insignias externas" (Mancebo Salvador 72). Indeed, Erífila is immediately alert to the implications of her state, referring to "esta desnudez villana" (1. 476, my emphasis) and she throws herself on the mercy of the men from the asylum, hoping that they will take pity on a noblewoman who has been robbed. They do not believe her story, however, without visual or material evidence of her status, manhandling her and comically 
assuming that her reference to lost jewels is her own mad tema, or hobby-horse, for which incarceration and treatment in the hospital is the only cure. ${ }^{9}$

\section{Desnudez decoded}

The unclothed body in Golden Age culture is, of course, a source of eroticism, as it is today Lope de Vega may well have been primarily interested in eliciting an erotic response to Erífila's undressing by her servant in act 1 of Los locos de Valencia. ${ }^{10}$ Images and depictions of unclothed bodies were common enough in visual and written culture, as we shall see, and these will have informed audience reactions to desnudez, on and off stage in the corral, including erotic responses. However, the decoding of the unclothed body in the theatre also depended on other commonly accepted interpretations of nakedness and could produce a variety of reactions amongst the spectators, both male and female, including those of pity or fear. It could also allow the dramatist to indicate time of day or dramatic location. Before focusing on its erotic power, I shall enumerate some of the most common "readings" of nakedness, concentrating on on-stage cases, but without attempting to be exhaustive in this exemplification.

\section{Poverty and Destitution}

An unclothed or partially clothed character was often to be understood as poor or destitute, as in the exemplification for the second definition of desnudo in Autoridades. Spectators would interpret as much from the evidence of the real world they inhabited, of course, as well as, culturally, from depictions of penury in picaresque literature and allegorical figures from drama, like that of the poor man in the auto sacramental. In Calderón de la Barca's El gran 
teatro del mundo (early 1630s), for example, Pobre is last in the queue to be given his costume and props by Mundo and discovers that, instead of receiving, he has to yield up what little he has and venture naked into the world. The deprived character's aphoristic polyptoton underlines his deflation and emphasizes the unfairness of it all, evoking sympathy in the Corpus Christi audience:

Mundo: $\quad$ A ti nada te he de dar, que el que haciendo al pobre vive nada del mundo recibe, antes te pienso quitar estas ropas, que has de andar desnudo, para que acuda (desnúdale) yo a mi cargo, no se duda.

Pobre: $\quad$ En fin, este mundo triste al que está vestido viste y al desnudo le desnuda (11. 598-607).

In the corral too lack of clothing is often indicative of poverty or destitution, even if that is a temporary state. ${ }^{11}$ In Lope's El caballero del milagro (1593), the unclothed state of the protagonist Luzmán indicates his renewed penury or, more specifically, his failure to succeed in passing as a Spanish nobleman, as Christina Lee has noted (59-61). Accosted by four masked men, the picaresque scoundrel is instructed, by one of them, Tristán, his aggrieved former servant, "Desnúdate presto, acaba", and replies "Ya señor estoy desnudo, / menos mal fuera morir" (11. 2863-65). Luzmán considers his state to be dishonourable and shameful then. The stage direction reads, "Vanse, y quede Luzmán solo y desnudo" (at 1. 2867). When he 
comes to Isabela’s house in this state, her line, “¡¿Luzmán de noche en camisa?!” (1. 2887), underlines that on stage desnudez implies wearing just underclothes. His nakedness can be seen as a visual representation of the poetically just failure of Luzmán's attempt to climb socially, as a return to poverty and misery at the very end of the play.

Other characters might lose everything, including clothing, in a shipwreck or other disaster, leaving them in the kind of parlous state in which Erífila found herself outside Valencia and Luzmán in Rome. One such is Leonido of Lope de Vega's La pobreza estimada (16001603). ${ }^{12}$ He washes up on the North African coast - "Sale Leonido mojado asido a una tabla" (fol. 45v) and, somewhat improbably, captures Audalla, the King of Algiers, himself in the process of disrobing in order to enjoy a moment of peace and solitude, bathing on the same Mediterranean beach. Both men (along with Leonido's sword) are desnudos; both are vulnerable in this state, though one is destitute and sodden while the other is newly disrobed, seeking brief solace in nature after escaping the tribulations of court life. Ironically, the Spaniard, the desnudo who has no possessions, becomes instantly wealthy by picking up Audalla's discarded weapons and taking advantage of - violating even - the bathing king's defenceless nakedness.

Innocence, humility, vulnerability and barbarism

The king's desnudez in Lope's play, coming after his long paean to the natural world (fols. 46r-46v), clearly situated within the menosprecio de corte / alabanza de aldea tradition, points us to another use of nakedness in the comedia: to represent vulnerability, humility or the innocence of humankind either before Original Sin in the Christian tradition or in the mythological Golden Age. Again, images would have abounded, from the classical and 
contemporary nymphs of the pastoral to visual images of hermits, saints and Biblical figures (such as those in the numerous life-like polychrome sculptures and paintings of the period). A good example is the depiction of the earthly paradise in dramatizations of the Old Testament Book of Genesis: in one such, Luis Vélez de Guevara's La creación del mundo (before 1610?), the opening stage direction asks the autor de comedias to produce a vision of the Garden of Eden with Adam “desnudo, con calzón y camisa de lienzo, y Dios Padre arriba, criándole de la manera que le pintan" (stage direction at 1. 1). In another of Vélez's religious plays, Las tres edades del mundo (date uncertain), Hombre, representing humankind and pursued by the devil, is described as "desnudo" (p. 239), having been expelled from the earthly paradise and later "queda desnudo en camisa de la cintura arriba" in a stage direction after the devil forces him to undress and become his slave (p. 251). Such depictions of unclothed characters are usually intended to remind the audience, as in the auto tradition, of humankind's vulnerability and humble place in God's creation. Naked when born, humans are destined to return to this state in death. These would have relied heavily on parallels with other visual depictions of nakedness (see for example figure 1).

[Figure 1]

The indios of the New World were often represented pictorially as unclothed though they were costumed in the theatre, conventionally carrying "arcos y flechas", as Ruano notes (83). Nevertheless, their primitive state (as judged through European eyes of the period) had some parallels with that of the occupants of the Garden of Eden and they could also be thought of as naked, with the implication of defenceless or perhaps "unarmed" as in the Latin nudus. (Indeed, indios feature in the exemplification of the first definition of desnudo in Autoridades.) Thus, in another Vélez play, La mayor desgracia de Carlos Quinto (1623), the 
Duque de Alba disparages Cortés's achievements against mere "gente desnuda" (1. 1503). Cortés himself responds that, "No fue gente tan cobarde / los desnudos, que no hicieron / cosas que dieron asombro" (11. 1525-27 / 11. 1871-73) and he offers to fight the fully-armed duke naked to prove that valour does not reside just in armour and arms. And the figure of the india also tended to be costumed on stage, as in Vélez's Las palabras a los reyes y gloria de los Pizarros (1625-30), where the Spanish conquistador meets Tucapela in a symbolic encounter. She is a "cacica, suelto el cabello, vestida de india muy a lo bizarro, con aljaba, flechas y arco, durmiendo en una hamaca tejida de dos árboles” (at 1. 637). However, in European iconographic representations of America, she is usually portrayed naked (in contrast to Europe, Asia and Africa) as Benito Quintana has illustrated and explained (10307) and audiences may well have had these images in mind when she appears (see figure 2). This nakedness of the female might have represented "the poverty and savage nature of America and its need to be conquered" (103) and the "barbarism of the New World" (107) with the lustful intentions of these near-naked women often forcing the Spanish men to face up to temptation (112). ${ }^{13}$

[Figure 2]

\section{Insanity and simplicity}

Nakedness was also commonly associated with insanity in early modern Spanish (and European) society and literature, though madness itself could sometimes be closely related to simplicity or innocence. Thus, in another early Lope play, Los donaires de Matico (before 1596), Sancho, posing as a "pastor rústico", undresses on stage in an attempt to prove his faithfulness to his lover, doña Juana (disguised as Matico) when they are briefly alone. On 
being interrupted by the count, who has brought Sancho to court in gratitude, after being rescued by him, he thinks quickly and pretends to be participating in a jumping competition, much to the nobleman's amusement:

¡De risa pierdo el sentido!

Él es de juïcio falto, que, para dar aquel salto, se ha desnudado el vestido (11. 826-29).

In a society quick to associate public nakedness with insanity, the removal of Erifila to the hospital de locos in the first act of Los locos de Valencia is plausible. Her state of undress in a public space is a sign of social dislocation, and she is taken to be a "loca errante" and forcibly incarcerated. ${ }^{14}$ Indeed, Hélène Tropé's research on the historical Valencian sanatorium includes analysis of the reasons why patients might be admitted, and desnudez "pudo ser interpretada como signo de locura", she confirms, as in the case of a certain Juana, who went around unclothed, "Juana que anava tota nua" (145). Huguet-Termes and Arrizabalaga, who have studied the hospitalization of the mad in Barcelona in the same period, note that " $[t]$ he nudity of one of the women interned might also have been understood as a sign of being deranged" (96). Certainly it is the case that as part of "un proceso general de admisión reglamentado por ... las Constituciones de 1589”, inmates were routinely undressed on arrival at the Valencian institution: "Todos los hospitalizados, locos inclusive, se veían desposeídos al ser ingresados de cuanto representaba un último vínculo con el mundo exterior (ropa y dinero)" (Tropé 304). Undressing and nakedness could also be a sign of an institutional response to madness, then. 
This reality was reflected in literary works. When Don Quijote and Sancho come across the mad Cardenio in the Sierra Morena in the first part of Cervantes's novel, "iba desnudo, la barba negra y espesa, los cabellos muchos y rebultados, los pies descalzos y las piernas sin cosa alguna..." (Cervantes 255). Shortly thereafter the mad knight himself decides to replicate the behaviour of Ariosto's Orlando, perhaps the best-known literary madman: "que antes me tengo de quitar todas estas armas y quedar desnudo como cuando nací, si es que me da en voluntad de seguir en mi penitencia más a Roldán que a Amadís” (278).

On the corral stage, Lope de Vega dramatizes Orlando's madness, from one of his favourite source works, in Angélica en el Catay (1599-1603). The two lovers who have caused Orlando's violent incapacity here take his nakedness as an indication of madness as he pursues them in a fury:

Angélica: ¡Roldán es este! ¡Ay de mí!

Medoro: $\quad$ Sin duda que loco está.

¿No ves que desnudo va? (11. 2268-70).

Indeed, at the end of act 2 Lope's stage direction indicates that Roldán should undress while exclaiming, “'Afuera ropa, ropa fuera digo!” (1. 1939), when he believes that the weight of his clothes is preventing him from jumping to reach Angélica on the moon.

Lope was not the only playwright to exploit the audience's association of nakedness with insanity and bring onstage an unclothed character: in Calderón's first play, La selva confusa (1623), Fadrique, who has been betrayed by his half-brother, Filipo, undresses as he is sent into exile so that he can show he is leaving behind every trace of his former land. He appears 
"sin el vestido" (at 1. 328) after one of Filipo's retainers has warned the audience that: "Como un loco va arrojando / los vestidos por la selva" (11. 322-33).

Insanity, then, whether real, feigned or suspected, was one of the main reasons for unclothed bodies to appear on the Golden Age stage. The on- and off-stage audience's response to the unclothed mad character will have varied according to genre and context, from fear at the prospect of violence to pity at an apparent decline in mental capacity, to derision and laughter at the abandonment of normal social comportment.

Time of day, lack of preparedness or self-control

There are other dramatic reasons for characters' desnudez on stage beyond its signalling poverty, innocence or madness. The partially dressed state can indicate conventionally that a character has recently risen from sleep, as Ruano de la Haza has noted (91), or has been bathing. In these cases the staging and (lack of) costume might reveal the time of day or location of the action to the spectator. Thus, Valerián, of Guillén de Castro's Los mal casados de Valencia (1595-1604?), opens act 2 “con una ropa de levantar, lavándose las manos; un paje dándole agua, y otro le da una toalla" (at 1. 1029). The audience realizes as a result that a night has passed since the events of act 1. In Rojas Zorrilla's Entre bobos anda el juego (1638), master and servant both appear half-dressed, mainly for comic effect, as don Pedro tries to speak to his beloved doña Isabel at two o'clock in the morning. ${ }^{15}$ The state of undress, as well as indicating unpreparedness, underlines the extent to which Pedro, usually resistant to Cupid's arrows, is smitten: Cabellera, roused from his bed at the start of act 2, will accuse him of madness but he cuts a comic figure as a half-dressed cloak and sword galán: 
Salen Don Pedro en jubón, con sombrero, capa y espada, y Cabellera, medio desnudo, por el patio del mesón.

Cabellera: ¿Adónde vas, señor, desta manera, medio desnudo?

Pedro: $\quad$ Calla, Cabellera (11. 943-44).

The nobleman, Nuño Osorio, of Lope's Las famosas asturianas (1610-12), is another character who enters undressed. Woken early by the sound of a violent commotion outside his room, he comes on-stage straight from his bed. Here the interrupted sleep or toilette is likely to cause offence to the character, especially if of a high social status, and a response of anger is probable.

Arrogance and cowardice

In Monroy y Silva's Fuente Ovejuna (date uncertain), a lack of clothing indicates a character's complacency or arrogance. The comendador appears "en cuerpo sin ropilla" (at 1. 2163) and scorns the complaints of his victim's father: "no se alborota el Comendador, sino se acaba de vestir mientras habla" (at 1. 2187). Ruano de la Haza persuasively argues that "la indiferencia del Comendador hacia sus vasallos es patente al comienzo de la tercera jornada cuando continúa vistiéndose impasiblemente y escuchando la música mientras el Regidor de Fuente Ovejuna, cuya hija ha sido deshonrada por él, se queja amargamente” (92). The aristocratic predator feels untouchable, blithely confident even when undressed, a state that might otherwise render him vulnerable. 
Desnudez can also be a marker of cowardice as in Calderón's Argenis y Poliarco (1627-29) when the gracioso, Gelanor, appears, having been robbed by bandits. The stage direction reads "salga Gelanor, criado, en cuerpo" (at 1. 137). Indeed, his outer clothes have been taken from him along with his sword, as he explains, comically:

les dejé que me llevaran

espada, capa y sombrero.

No tenéis que prevenir

armas, porque ya yo llevo

esta pistola, que acaso

se me quedó en los griguiescos,

con que podemos matarlos (11.143-49). ${ }^{16}$

The servant is described by his master, Poliarco, as "cobarde" (1. 167) when he admits absurdly that he kept the gun hidden in his underclothes in case the thieves saw it and took it too. In this case, the disrobing simply underlines visually (and comically) one of the gracioso's stock characteristics.

\section{A de-sexualized female body}

Some of the meanings of these various, less overtly erotic, displays of the unclothed body on the Golden Age stage are condensed into one of the most interesting off-stage cases of nakedness in the comedia nueva. In Lope's above-mentioned Las famosas asturianas, which dramatizes a Spanish Reconquest myth, the defining moment of the play cannot take place on 
stage since it involves the public display of a female body too naked to be shown to the audience.

Doña Sancha has been selected by lot as one of the hundred maidens given annually as tribute by the northern Christians to the Muslims of Córdoba. Accompanied by the Christian soldiers and about to be handed over to the waiting Moors, Sancha decides to travel naked and removes her clothes. Toribio explains that:

Los blancos brazos y los tiernos pechos, que non se descobrieron en su casa a Sol, su prima, ni a Leonor, su amiga, los trae descobiertos por el campo (11. 2246-49).

The Christians, including the famous Nuño Osorio, who has fallen in love with this mujer varonil, naturally feel she is exhibiting symptoms of madness faced with her grim fate, "Non puede, amigos, ser de otra manera, / porque con seso non se descobriera" (11. 2241-42). They feel pity and embarrassment at her state of mind signalled by her state of undress.

However, Sancha's nakedness is in fact part of a strategy to shame the menfolk into bellicose action: she puts her clothes back on when she sees the Moorish army and is summoned on stage to explain her behaviour, which now seems to show signs of sanity. She does so in a powerful speech reminiscent of Laurencia of Lope's Fuente Ovejuna:

Las mujeres non tenemos vergüenza de las mujeres; 
quien camina entre vosotros,

muy bien desnudarse puede,

porque sois como nosotras,

cobardes, fracas y endebres

fembras, mujeres y damas;

y así, no hay por qué non deje

de desnudarme ante vos,

como a fembras acontece.

Pero cuando vi los moros,

que son homes, y homes fuertes,

vestíme, que non es bien

que las mis carnes me viesen.

¿Qué honestidad he perdido

cuando vengo entre mujeres? (11. 2337-52)

Doña Sancha's bare-breasted Asturian odyssey does not inspire erotic thoughts in the male soldiers, we are informed, and given the epic / historical genre of the play, the audience's response to learning of the heroine's state of undress may well have differed substantially to more typical reactions to news of a character's nakedness in a comedia urbana or de capa y espada. Nuño Osorio himself explains that he has not been able to look at her through shame (1. 2269) and another soldier, Anzures, says that even the most virile of the men dare not set eyes upon her or, if they do, it is not with "codicia del su amor" (1. 2274) but with "dolor, viendo tal dama / que de pesar su honestidad infama" (11. 2275-76). 
In fact the brave, socially rebellious nakedness of Sancha inspires the Christians to more traditionally manly actions, worthy of the spirit of the Reconquest, and they defeat the Muslims with their women alongside them on the battlefield. Here female nakedness, used deliberately and ingeniously as a strategy to provoke a certain reaction, embarrasses the men into military action, to righting the upturned social world, not thoughts of love or sex. Unlike most of the cases we have considered so far, Sancha's nakedness is kept off stage for reasons of decorum but its display is inspirational within the play. She de-sexualizes her female body to shame the male characters who have forgotten how to use their own emasculated bodies for the purposes of military glory.

Although this fascinating example from Lope's Reconquest drama occurs off stage, the unclothed body, if not the naked body, male and female, does appear commonly enough on the Golden Age stage and reasons for its presence along with ways of interpreting it are several. To summarize so far: in different circumstances it may indicate a character's poverty, innocence, weakness, vulnerability, madness, lack of preparedness, cowardice or arrogance (and we might add savagery, barbarism and lustfulness if we include the New World indios); it may help to indicate the time of day or the location of a scene; and it may incite feelings ranging from tenderness and piety to pity and revulsion or provoke laughter and surprise both on stage and in the auditorium.

\section{Eroticism}

The most common reason for a dramatist to bring a partially clothed character on stage and, more frequently still, to include a description of their off-stage nakedness, is to provoke a sexual frisson, however. Unclothed figures often suggest sexual availability and spark erotic 
desire, as the moralists feared when they condemned their appearance on the corral stage. Even those whose nakedness is meant to elicit a less visceral, more affective or intellectual response, may still produce an erotic thrill for the spectator, especially in a period when the disrobed figure is taboo. Indeed, in her study of the erotic in Golden Age theatre, Esther Fernández recognizes that, though scenes containing nakedness, like the one featuring Monroy's arrogant comendador, can, on occasion, be "asépticas de toda intencionalidad erótica" (154), in fact, especially when the usually well-covered actress's body is involved, "la carga erótica de la escena era imposible de disipar" (155). Kenneth Clark, in his study of the nude in art, a medium related to theatre through their common creation of visual effects, felt it "necessary to labour the obvious and say that no nude, however abstract, should fail to arouse in the spectator some vestige of erotic feeling" (6).

Turning to the more overtly erotic unclothed bodies in the comedia nueva, then, it is first worth reaffirming that they are mostly kept off stage. This is invariably the case when nearor complete nakedness is involved. Nevertheless, some on-stage scenes do present figures usually female - who are partially clad and thus all-the-more irresistible to the men who set eyes on them. Monroy's comendador, whose unclothed state we briefly examined, is himself aroused by his night-time excursion into doña Flor's room where he finds her (presumably in the vestuario): “[d]escúbrese a Flor, que estará medio desnuda, durmiendo en una silla, con luz” (at 1. 1936). In Lope de Vega's El castigo sin venganza (1631), the attraction Federico feels for his soon-to-be step-mother, Casandra, is partly explained by his rescuing of her when she has been bathing her snow-white feet in the water of the river: "bañando en ella los pies / para que corriese perlas," as Rutilio puts it (11. 534-35). ${ }^{17}$ After the conde has carried the barefoot Casandra on to the stage his servant, the gracioso Batín, entering with her maid, Lucrecia, makes mention of the "ninfas tan bellas" (1.359) who were enjoying the riverine 
setting before their mishap. This is a further invitation - albeit partly comic in tone - for the audience to imagine the idealized scene of female bathing, exploiting poetic or pictorial sources with which they were familiar, a technique to which we shall return.

In Antonio Coello’s “tragedia más lastimosa de amor”, El conde de Sex (1633), the queen, Isabela (Elizabeth I of England), twice appears on stage only partially clothed: first, in act 1, she enters "en enaguas y cotilla, a medio vestir y con mascarilla" (p. 403b) and towards the end of the play she attempts to recreate this moment (when she first met the Earl of Essex): "Sale la reina, con una luz y de la suerte que salió al principio de la comedia, con máscara y enaguas" (p. 418a). ${ }^{18}$ This first time she entered was when she had just survived an assassination attempt (thanks to the conde's intervention) while dressing after bathing in the River Thames. The second, more overtly erotic entrance permits Elizabeth to express her love for Essex at a point when, as queen, she has to sign his death-warrant. The stark difference in her costumes - as would-be lover and as queen - underlines the clash of love and duty, with the erotically (un)attired body and masked face an expression of her female desire and strong attraction to Essex, as she admits self-consciously. Perhaps there was an especial thrill for the Golden Age audience in seeing Anne Boleyn's daughter, rival to the always austere King Philip II, consumed with a lust so evident from her unclothed body, but this is a rare glimpse of an undressed queen, as María Cristina Quintero has argued (152-56).

Another female character who appears on stage "en enaguas" is doña Mayor of Tirso de Molina's comedy, Desde Toledo a Madrid (1622-23). ${ }^{19}$ She returns to her bedroom at the start of the play to find Baltasar has entered it illicitly (after eluding his pursuers at night). The stage direction reads: "Duérmese [Baltasar] y sale Casilda, criada, con candelero de plata y vela encendida de cera, alumbrando a Doña Mayor, en enaguas, con un rebociño..." (at 1. 
209). ${ }^{20}$ The maid exits, leaving Mayor to remove her rebociño as she prepares to return to bed, but she faints on noticing the male stranger asleep on a chair in her room. As if Baltasar's handling and description of her intimate clothing and still warm bed and then her nearly naked, candle-lit appearance on the scene were not erotic enough, he then describes feeling her person in the dark, stressing, unusually, the sense of touch. The scene would have been performed in daylight, of course, making the encounter potentially more erotic, perhaps with an element of comedy:

\author{
Tienta los cabellos y la ropa de la dama. \\ ¡Válgame Dios! Si el sentido \\ del tacto vengo a creer, \\ esto que toco es mujer: \\ los cabellos y el vestido \\ aumentan mi confusión (11. 285-89).
}

These four scenes featuring partially (un)dressed women and heterosexual male characters attracted to them must have been played for their eroticism on the corral stage. The costumes, props and acting may have verged on the risqué in such moments, as the plays' interpreters sought to underline the evident sexual attraction between the characters, not always mutual and sometimes voyeuristic, but vital to the plays' plots and the playwrights' ability to affect the audience emotionally, to capture their imaginations and enrapture their senses.

However, the body could be even barer and the contact between the couple even more intimate if the scene took place off stage, and many dramatists stoked the erotic imaginations 
of their audiences by taking advantage of the possibilities afforded by description, by vicarious voyeurism, by provocative images created in words. Profeti has claimed as much when writing that, “[e]n el teatro barroco, pues, la escena erótica más auténtica y profunda es la que no existe, la que se sitúa más allá, la que la palabra evoca por negarla" (73-74). Such scenes rely on the existence of an "intermediario dramático entre la escena erótica y el receptor, describiendo la sensualidad de lo experimentado o visto y compartiendo la exaltación de sus sentidos con el lector / espectador” (Esther Fernández Rodríguez 114).

Scholars have remarked upon the heightened role of poetry in these descriptive recreations of erotic scenes in the comedia nueva, such as those featuring the bathing nude. MacCurdy, who first attempted to account for the prevalence of this motif, saw in the proliferation of such descriptions amongst the playwrights of Calderón's generation, notably Rojas Zorrilla, the influence of Góngora's Polifemo, with its abstract and metaphorical erotic account of the love-making of Acis and Galatea. For this critic the poetry was the scene's "raison d'être": in a culture in which the nude was all but absent from painting, he argues, "Baroque poets and dramatists compensated bountifully for the lack with their voluptuous word-pictures of the bathing nude" (39). Profeti (73) and Esther Fernández Rodríguez also underline the poetic eroticism of descriptions of women bathing with the former examining such content in Rojas Zorrilla's Entre bobas anda el juego and the latter in Mira de Amescua's Lo que puede una sospecha. Fernández Rodríguez argues that "esta modalidad de osado cuadro descriptivo a través de un contenido poético que resulta visualmente tan sugerente ... permite al lector / espectador re-crear en su mente la sensualidad de la escena sin necesidad de verla escenificada de manera más patente" (125-26). 
This is no doubt true and we shall come to examine an example of the bathing scene in order to assess its poetic eroticism, but what is less frequently explored is the role of visual culture in helping the audience imagine these scenes, perhaps especially important in the minds of the more cultured spectators. When they kept the scantily-clad figure off stage, dramatists did so in order to create scenes that actors were not permitted to embody. They took the responsibility for its portrayal away from the ingenuity of the autor de comedias and the costume and bodily movement of the actor, placing it instead in their own poetic and rhetorical flair, their skill in ecphrastic description, and trusting in the vivid imaginations of the audience, whose desires they might inflame. Along these lines Frederick de Armas has suggested that, through ecphrasis of Italian mythological paintings in his plays, "Lope enhances the sparse elements of scenery in the public theaters with [his] vision of erotic and aristocratic opulence that calls upon the sense of sight and thus brings forth from recollection artistic images in the connoisseur" (173). And demonstrating how artistic representation of the erotic can tantalize, Lope has César, of La quinta de Florencia (1598-1603), describe the paintings in his house outside Florence along with his response to them:

Puse famosas pinturas de aquel artífice en ellas, que en el pincel y en el nombre es un ángel en la tierra.

Allí mil ninfas desnudas daban con sus carnes bellas imaginaciones locas entre soledades necias. Miraba a Venus y Adonis 
una tarde en una siesta,

el con el bozo dorado,

y ella con doradas trenzas

Cupidillo, que jugaba

con un carcaje de flechas,

- yo pienso que aunque pintado

es discreción que se tema -

diome deseo de amar

una mujer como aquélla (11. 289-300; 305-10).

Even in a painting, Cupid is to be feared for the effect he can have on the viewer and indeed César is smitten with love for a woman like Venus as he day-dreams in front of her image. The recreation of a painting of naked figures - nymphs by a stream, Venus and Adonis (see figure 3), other Ovidian tales, particularly of Jupiter, in various forms, appearing to young women - is seen here to instigate an awakening of erotic desire. In de Armas's words, Lope's "speaking pictures tantalize the viewer to approach erotic bodies and contemplate forbidden desires" (182). By invoking such painted scenes dramatists exploited, at one remove, the power of visual art to enhance their drama and we see references to such paintings (or painting in general) in the set-piece descriptions of off-stage nudes in the comedia nueva. ${ }^{21}$

[Figure 3]

César's ecphrasis in Lope's play is a description of "real" pictures containing erotic desnudos. However, on-stage descriptions of scenes which have occurred off stage (during or 
before the action of a play) are reminiscent of such artistic creations and depend on pictorial art for their effect. In these stylized set-pieces, then, the focus of the dramatist on the naked body is primarily intended to be erotic. It often involves describing or suggesting what cannot conventionally be seen directly by an audience but is known from visual culture and excites sexual desire. Usually, to take the example of the bathing woman, the man who is watching falls in love with her and describes her beauty in highly wrought Petrarchan terminology imbued with culto syntax and lexis. Thus, in the aforementioned tragedy, El conde de Sex, Coello depicts Queen Elizabeth's off-stage bathing through the Gongorine description of the conde, who falls for her beauty, though when he espies her he is meant to be visiting his lover, Doña Blanca. Because she is wearing a half mask, the queen's identity at first remains a mystery to him. The conde's protracted erotic description of the scene gradually builds to the climax of Isabela's disrobing, washing her legs in and then drinking from the river. The queen is then described drying and dressing herself. She is thus "presented as an eroticized object inadvertently performing a striptease for the count's scopophilic delectation" in the words of Quintero (155). The count's relation, made incongruously (but not uncommonly in such cases), to the gracioso, Cosme, could almost be the ecphrastic description of a mythological painting and is certainly an attempt to fire the erotic imagination of the spectator. It is otiose to link the poetic description of the bathing nude to an individual canvas in this case but Titian's Diana and Acteaon (figure 4), with its inadvertent voyeurism, might be the sort of image that would enter the more cultured audience-member's mind or his Venus rising from the sea (figure 5) in which the single nude's legs are immersed in the water as she wrings out her wet hair.

[Figure 4]

[Figure 5] 
Awaiting nightfall and his tryst with Blanca, the count keeps losing himself in the dense foliage of the quinta's grounds before hearing a noise which he follows, "árbitro el oído", until his sense of sight takes over:

Recojo la atención para la vista;

ella penetra ramas, y yo veo

una mujer divina,

reclinada en la margen cristalina,

quitarse, descuidada,

azul cendal y media nacarada,

negros después coturnos al pie breve,

que, primavera errante, flores llueve;

las dos colunas bellas

metió dentro del río, y como al vellas

vi cristal en el río desatado

y vi cristal en ellas condensado ... (p. 404b). ${ }^{22}$

The mythological aura is prolonged with references to envious river nymphs, and the chariot of the Sun which finally descends to bring darkness to the scene (encouraging the would-be assassins to emerge and attack the queen).

The description by the count lingers upon the queen's body, mainly her feet, legs and hair as well as the lower part of her face whose whiteness contrasts with the black half-mask that she 
is wearing over her nose and eyes (described as an unlikely marriage of jet and ivory). He also boldly presents her nakedness as her perfect state, eventually "clouded" by the irksome presence of clothing:

Y luego en acabando de enjugarlas, a cubrir empezó sus dos colunas con dos nubes de nácar importunas; adorno suele ser, pero ¿quién duda que era mayor adorno estar desnuda? (p. 404c) ${ }^{23}$

Coello's bold sensuous poetry evokes in the mind's eye a scene of undressing and nudity that clearly cannot be shown in the corral. This is eroticism for its own sake, as set-piece "wordpicture" (in MacCurdy's phrase) for which the action stops and the imagination is freed, but it is also eroticism with a purpose that can be read by the audience. The count's description of the bathing nude is important for the development of the plot of El conde de Sex as the queen and earl will fall in love: he admires her naked beauty; she his heroism in defending her in her vulnerable state from the would-be assassins. The queen's state of undress, on stage ("en enaguas", as described above) and off stage, helps the playwright to characterize her as well: we have already seen with Casandra of Lope's El castigo sin venganza, that sight of or reference to a woman's bare feet or loose hair tends to imply that the character will become a victim of her own uncontrolled amorous passion, as Kossoff argues. And, what is more, the illicit nature of the voyeurism suggests that the Earl of Essex will come to a tragic end: first he himself sees the woods as a perilous labyrinth with the river an "hilo de plata" (p. 404b) but, above all, though Ovid's story of Acteon and Diana is not mentioned explicitly, there are echoes of the chaste goddess's toilette in his description: the dense woods and shaded pool, 
the woman as goddess, the focus on the washing of hair and limbs and the image of Diana / Elizabeth's clouded cheeks. ${ }^{24}$

The count's relation serves a number of dramatic purposes then, but the explicit nature of its eroticism is, I would argue, its most notable feature. It is just one of the many occasions in which stories or images involving nakedness substitute for the display of the unclothed body on stage in the comedia nueva. Although the descriptions of female bodies decorously avoid overt mention of their most intimate anatomical features, usually "covered" by a veil or a towel or immersed in crystalline waters, this "ostentación erótico-poética" forms part of an attempt to "duplicar discursivamente la sensualidad estética de un desnudo femenino", as Esther Fernández Rodríguez aptly puts it (125). The dramatist's techniques are sophisticated but one might single out the frequent presence of tantalizing obstructions to the voyeur's view of the scene reminiscent of the painter's art: foliage or wisps of material or the bathing lady's attendants obscure the body as in Rojas Zorrilla's Entre bobos anda el juego: "Sale a la orilla, donde verla creo; / pónenseme delante, y no la veo" (11. 1045-46). ${ }^{25}$ And poetic conceits suggest (a desire for) sexual union or at least an erotic sensuality, as when Isabel's personified damp camisa clings to her shapely body "dando abrazos pegadizos / al animado marfil" in Lo que puede una sospecha (Fernández Rodríguez 143), or body (the Petrarchan lady's "ice") and river water (the pool formed from the Thames bleeding snow) merge into each other in El conde de Sex: "No supe si las aguas que se vían / eran sus pies, que líquidos corrían" (p. 404b).

The nude bathing scene with its counterpart in visual culture is perhaps the most overtly erotic exploitation of off-stage nakedness in the comedia but images of nakedness, even if fleetingly or subtly recreated in the spectators' minds, recur fairly frequently. Some would be 
meant to exploit the frame of reference of the more cultured spectators such as when Prince Enrique steals into the walled garden to visit Mencía in Calderón's El médico de su honra (early 1630s) comparing himself to Acteon glimpsing Diana bathing (11. 1049-50; see figure 4). With the Ovidian reference he both underlines the illicit, erotic intentions of his visit and betrays his personality, exaggerating or misunderstanding the danger he is in as well as making assumptions about Mencía's character. He is in fact above the law and, ironically, it is Mencía, no vengeful deity, who will die as a result of his indiscretion and lust. Here the image created by Enrique (whether dependent on Ovid or Titian, verse or painting) is not reflected on stage or in any of the off-stage action but it is evocative for the audience and, above all, characterizes Enrique as an inconsiderate and unworthy prince.

In Lope's El castigo sin venganza, the tragedy's most erotic moment (when Casandra realizes that Federico is in love with her and so encourages him into her bed) is characterized by her conjuring, in their dialogue, of two images involving naked mythological figures. She knows that her step-son lives largely in the realm of his imagination and having asked him if he has fallen in love with some unattainable bronze image, nymph or goddess, she advises him to speak up and declare his passion to whoever his beloved might be:

Dile tu amor, sea quien fuere, que no sin causa pintaron a Venus tal vez los griegos rendida a un sátiro o fauno. Más alta será la Luna, y de su cerco argentado 
bajó por Endimión

mil veces al monte Latmo (11. 1490-97).

Casandra calls to Federico's (and the audience's) mind firstly images common to emblem books and Renaissance painting, of the naked or partially-clothed Venus accepting the advances of or being gazed at by an ugly faun (figures 6 and 7), and secondly to the nude Endymion and the goddess of the moon gazing upon him, asleep, also a popular subject for painters. Both scenes suggest illicit, scarcely credible love but they both evoke potent sexual desire - female desire for the naked male figure in the latter case - and are traditionally represented erotically. Although Casandra cannot appear in a state of undress on stage in this scene and cannot openly seduce Federico, she can conjure these sensual images of acquiescence and requited desire for her step-son to dwell upon, whether from paintings in the palace or his reading of mythology. ${ }^{26}$

[Figure 6]

[Figure 7]

Another myth involving nakedness and eroticism to which both Renaissance painters and Golden Age dramatists had quite frequent recourse was that of Cupid and Psyche.

Playwrights again chose it deliberately to evoke an intimate, nude scene, vital to the play, but that could not be reproduced on stage. Even in López de Cartagena's 1513 translation of Apuleius's Golden Ass, the classical text from which the story is taken, Psyche's sexual arousal on at last seeing the body of her secretive lover is clear (Apuleyo 174-75). The tale, in which hot oil from Psyche's lamp inadvertently spills upon and wakens the sleeping god of love, becomes a short-hand way of referring to and allowing the audience to re-imagine an 
actual sexual encounter or a scene of voyeurism as in, for example, Lope's La viuda valenciana (1599-1600). ${ }^{27}$ In this work Leonarda plays Cupid, the invisible mistress in the common reversal of the myth, to Camilo's Psyche. ${ }^{28}$ When Floro suggests that he use the lamp to see who his sleeping lover really is, Camilo replies:

Podráme costar la vida,

Floro, aqueste atrevimiento;

que si Psiquis vio al Amor,

a quien ascuras gozaba,

perdió la gloria en que estaba,

y negoció su dolor (11. 1827-32).

He prefers to continue the sexual relationship with his mysterious lady "y ser / sin ojos enamorado" (11. 1835-36), rather than risking his future access to this "gloria."

In another Tirso play, La huerta de Juan Fernández (1626), a related legend is evoked in Tomasa's erotic unveiling of her master as a woman, Doña Petronila. In this case the servant, also pretending to be a man, provides a 200-line explanation for and account of her unauthorized presence in her mistress's room: when removing Petronila's boots earlier that night she had noticed the petite size and fine condition of her feet and had later returned due to her suspicions about her true sex:

“¡Vive Dios! (dije entre mí), pie adarme, que os han criado más para alfombra y estrado, 
que para que andéis ansí.

Sospechas hembras, dudar

en esto será mentir:

mejor sois para parir,

mi pie, que para engendrar" (11. 628-35).

Tomasa casts herself as the mythical conde Partinuplés (1. 552), like Psyche, trying to discover by candle-light and in secret the truth about his disguised lover, who has forbidden him to look at her. The hot wax from the candle used in the investigation falls upon the lady's breast, wakening her and putting him in danger. Tomasa expresses no sexual interest in Petronila but her description of looking carefully at her mistress for evidence of her female sex is once again potentially titillating to a portion of the audience, though this might have been mitigated somewhat with its being couched as an anti-Petrarchan, comic-erotic description beginning at the foot and moving up the body to the hair.

Evocations of off-stage male or female nudity do not always depend upon the exploitation of myth or images from paintings or emblems, however. Playwrights can make a simpler and more popular appeal to characters' (and the audience's) imaginations, as in Lope's $E l$ ruiseñor de Sevilla (1603-08), inspired by Boccaccio's bawdy tale (Decameron V, 4), in which Lucinda explains how she has fallen in love with don Félix after seeing him dressing and undressing from her window:

Por entre estas celosías

que cubren estas ventanas

le veo vestir mil veces 
y desnudarse otras tantas,

y Amor, que nunca para,

entra por ellas a abrasarme el alma (11. 435-40).

The protagonist's gestural indication of the very blinds and the windows through which she spies on Félix, together with her use of the habitual present tense, lend an immediacy and proximity to the male undressing. Similarly, in Guillén de Castro's Los mal casados de Valencia, a voyeur, the escudero Galíndez, witnesses and reports the cavorting of don Álvaro and Elvira (probably in the curtained-off vestuario). It is not clear in this case that they are unclothed (as they have just left the stage) but the servant, thinking Elvira is a man, believes he is watching the pecado nefando (11. 2185-98) through a hole in the door.

In two of Lope's plays, La varona castellana (1599) and La discreta enamorada (1604-08), characters invent for their own ends scenes of nakedness alleged to have taken place off stage, though their fictional nature does not lessen their erotic power. ${ }^{29}$ In the former play, the cowardly servant Ordoño has to improvise the narration of a scene in which he says he has witnessed the soldier León (really María in male disguise) cavorting with the prostitute Celia and then fleeing across a roof. The latter is "desnuda" (1. 1846) and "he" "en camisa" (1. 1850). Don Vela, who has been pursuing María (correctly believing her to be a woman), had sent Ordoño to spy on her tryst and discover her true sex. Ordoño makes up his explicit story and Vela re-tells it to María, allowing her to pick it up again and add extra details, evoking the invented scene and its naked protagonists for the third time. Her "dama" (Celia) was, she says:

cuasi en cueros, el cabello 
suelto, quebrando las tejas,

dando el viento en las madejas

que bañaban pecho y cuello (1l. 1917-20).

Whether such a sexual encounter has taken place or not, "tenía que ser complementada por la activa imaginación del público”, in the words of Esther Fernández Rodríguez. ${ }^{30}$ The erotic force of such narrated scenes will have depended on the actors' skills and the audience's imaginative resources.

In Lope's La discreta enamorada, Fenisa, the discreta of the title, is able to manipulate her husband-to-be, the old capitán, Bernardo, by predicting how he will react to certain of her words and actions. Thus, for example, by telling him that his son Lucindo, for whom she has fallen, is competing with him for her attentions, she is able to send her beloved a message, via his angry father, that she loves him and wants to be wooed by him. In the second act of the comedy, in order to encourage the absent Lucindo to visit her grille so that they can maintain communication, she dreams up a scenario designed to infuriate the older man. She complains to the jealous Bernardo that his son disturbed her sleep the previous evening:

Anoche sentí ruido

a la reja, y diome un miedo,

que me privó de sentido.

Levántome como puedo,

sin luz no acierto el vestido,

topo el manteo en efeto,

salgo a la reja, y en ella ... 
¿De qué estáis tan inquieto? (p. 102)

The description, in the vivid present tense, of his betrothed Fenisa rising from her bed and, barely covered, stumbling towards the grille at which Lucindo is apparently present is enough to enrage her suitor. Her last line here, after the telling ellipsis, is an implicit stage direction, suggesting as much. Fenisa's self-portrait, a vividly drawn scene of apparent innocence and clear eroticism, hinting at the fruits of his forthcoming marriage night, together with the possibility of this unclothed body being seen and claimed by another man - his own son - is too much for Bernardo. However, in subsequently trying to stop Lucindo's (imagined) behaviour, he inadvertently acts as a go-between in the youngsters' relationship. Fenisa does not remove her clothes here, the scene she describes does not even take place, and yet she has strategically evoked an image of an unclothed female body, to titillate and deceive, and outwit the patriarchy, represented by the old captain. Her body will be reserved for his son when her plan comes together in the comic dénouement and the young couple consummate their relationship.

\section{Conclusion}

It is hardly surprising that the unclothed body, central to Western art forms (most particularly visual culture), often idealized but imbued with multiple meanings, should be well represented in the comedia nueva on the corral stage. The actor-managers of the period understood conventionally how to present the desnudo and the desnuda when the action or stage directions called for their presence in a play. The audience would have responded to the context, the dialogue and the (lack of) costume to interpret the meaning of each unclothed body, depending on their level of culture and particular sensibility. Bodies were displayed for 
reasons which were not solely erotic, but the way that unclothed actors were looked at could not be controlled by dramatist or autor de comedias and this spawned anxiety amongst the moralists and anti-theatre lobby.

Off stage, unseen, but poetically or imaginatively created, the naked body is interesting for a number of reasons too. Its evocation helps us explore the dividing line between what could and could not be shown on stage with the fuller off-stage nakedness allowing the possibilities for unashamed (or less-ashamed) eroticism to be developed, both titillating the public and adding depth and complexity to characterization and plot. However, the artistry in these offstage evocations is also worthy of attention and study. Dramatists had at their disposal a range of recourses: the merest hint of nakedness might be brought to the paying public's mind, thanks to knowledge of a myth, perhaps depicted in a famous painting; an audience might be encouraged to imagine a scene or a picture featuring a naked figure, male or female, to help them to engage emotionally with the plot of a play involving a passionate love affair; and the reader or spectator could delight in ecphrastic or highly wrought poetic set-pieces, describing the nude (usually female in this case) as if she were before their eyes. All of these possibilities were woven into the rich fabric of the comedia nueva helping it to flourish and appeal to readers and audiences both cultured and popular. ${ }^{31}$

\section{Works Cited}

Apuleyo. El asno de oro. Edited by Carlos García Gual. Translated by Diego López de Cortegana, Alianza, 2000. 
Argente del Castillo Ocaña, Carmen. "De la realidad a la ficción: el vestido en la escena." Las mujeres en la sociedad española del Siglo de Oro: ficción teatral y realidad histórica, edited by Juan Antonio Martínez Berbel. Universidad de Granada, 1998, pp. 161-84.

Boadas, Sònia. "Los grabados de Virgil Solis: una fuente iconográfica para las comedias mitológicas de Lope de Vega.” Hispanic Review, vol. 84 no. 4, 2016, pp. 427-57.

Calderón de la Barca, Pedro. Argenis y Poliarco. Edited by Alicia Vara López, Iberoamericana, 2015.

---. El gran teatro del mundo. El gran teatro del mundo / El gran mercado del mundo. Edited by Eugenio Frutos Cortés, Cátedra, 1985.

---. El médico de su honra. Edited by D. W. Cruickshank, Castalia, 1989.

---. La selva confusa. Edited by Erik Coenen, Reichenberger, 2011.

Carrascón, Guillermo. "Disfraz y técnica teatral en el primer Lope.” Edad de Oro, vol. 16, 1997, pp. 121-36.

Castro, Guillén de. Los mal casados de Valencia. Edited by Luciano García Lorenzo, Castalia, 1976.

Cervantes, Miguel de. Don Quijote de la Mancha. Edited by Francisco Rico, Crítica, 2001. Clark, Kenneth. The Nude. Penguin, 1985.

Coello, Antonio. El conde de Sex. Dramáticos contemporáneos a Lope de Vega. Edited by Ramón de Mesonero Romanos, 2 vols., Atlas, 1951, II, pp. 403-20.

Cotarelo y Mori, Emilio. Bibliografía de las controversias sobre la licitud del teatro en España. Edited by José Luis Suárez García, Archivum, 1997.

de Armas, Frederick A. The Invisible Mistress: Aspects of Feminism and Fantasy in the Golden Age, Biblioteca Siglo de Oro, 1976. 
---. “Lope de Vega's Speaking Pictures: Tantalizing Titians and Forbidden Michelangelos in La quinta de Florencia." A Companion to Lope de Vega, edited by Alexander Samson and Jonathan Thacker, Tamesis, 2008, pp. 171-82.

Diccionario de Autoridades. www.rae.es/recursos/diccionarios/diccionarios-anteriores-17261996/diccionario-de-autoridades.

Diccionario de la Lengua Española. dle.rae.es/?w=diccionario.

Diez años de la Compañía Nacional de Teatro Clásico. Cuadernos de Teatro Clásico, vol. 9, 1996.

Fernández Rodríguez, Daniel. Entre corsarios y cautivos: las comedias bizantinas de Lope de vega, su tradición y su legado. Iberoamericana / Vervuert, 2019.

Fernández Rodríguez, Esther. Eros en escena: Erotismo en el teatro del Siglo de Oro. Juan de la Cuesta, 2009.

Ferrer Valls, Teresa. "Damas enamoran damas, o el galán fingido en las comedias de Lope de Vega." Amor y erotismo en el teatro de Lope de Vega. Actas de las XXV Jornadas de Teatro Clásico de Almagro, edited by Felipe B. Pedraza Jiménez, Rafael Cañal and Elena Marcello, Universidad de Castilla-La Mancha, 1997, pp. 191-213.

Henry, Melanie and Jonathan Thacker. "Self-Construction and the Imagination in the Drama of Lope de Vega and Cervantes." Imaginary Matters: Realizing the Imagination in Early Modern Iberian Culture. Bulletin of Spanish Studies, vol. 93, no. 7-8, 2016, pp. 1415-44.

Huguet-Termes, Teresa and Jon Arrizabalaga. "Hospital Care for the Insane in Barcelona, 1400-1700." Madness and Melancholy in Sixteenth- and Seventeenth-Century Spain, edited by Elena Carrera. Bulletin of Spanish Studies, vol. 87, no. 8, 2010, pp. 81-104. 
Kossoff, A. David. "El pie desnudo: Cervantes y Lope.” Homenaje a William L. Fichter: Estudios sobre el teatro antiguo hispánico y otros ensayos, edited by A. David Kossoff and José Amor y Vázquez, Castalia, 1971, pp. 381-86.

Lee, Christina H. The Anxiety of Sameness in Early Modern Spain. Manchester UP, 2016.

MacCurdy, Raymond R. "Women and Sexual Love in the Plays of Rojas Zorrilla." Hispania, 62, 1979, pp. 255-65.

Madroñal, Abraham. "Glosario de voces comentadas relacionadas con el vestido, el tocado y el calzado en el teatro español del Siglo de Oro.” El vestuario en el teatro clásico español del Siglo de Oro. Cuadernos de Teatro Clásico, 13-14, 2000, pp. 229-301.

Mancebo Salvador, Yolanda. "Desnudos honorables. Las famosas asturianas de Lope de Vega." La desvergüenza en la comedia española. Actas de las XXXIV Jornadas de Teatro Clásico de Almagro, edited by Felipe B. Pedraza Jiménez, Rafael González Cañal and Elena E. Marcello, Universidad de Castilla-La Mancha, 2013, pp. 71-88. Monroy, Cristóbal de. Fuente Ovejuna. Fuente Ovejuna (dos comedias). Edited by Francisco López Estrada, Castalia, 1985.

Morley, S. Griswold and Courtney Bruerton. The Chronology of Lope de Vega's comedias. The Modern Language Association of America, 1966.

Núñez de Castro, Álvaro. Libro histórico político, solo Madrid es corte y el cortesano en Madrid. Andrés García de la Iglesia, 1658.

Ovid. Metamorphoses, Books 1-8. Translated by Frank Justus Miller. Revised by G. P. Gould, Loeb Classical Library, 1916.

Pontón, Gonzalo. “〈Representar lo que soy»: identidad y metateatro en Las burlas de amor.” Anuario Lope de Vega, vol. 26, 2020, pp. 86-108.

Portús Pérez, Javier. Pintura y pensamiento en la España de Lope de Vega. Nerea, 1999. 
Presotto, Marco. "Vestir y desvestir: apuntes sobre la indumentaria en la dramaturgia del primer Lope de Vega.” Annali di Ca' Foscari, vol. 34, nos. 1-2, 1995, pp. 365-83.

Profeti, Maria Grazia. "La escena erótica de los siglos áureos: poesía, novela, teatro." Discurso erótico y disucrso transgresor en la cultura peninsular, siglos XI a XX, edited by Myriam Díez Diocaretz and Iris M. Zavala. Tuero, 1992, pp. 57-89.

Quintana, Benito. “Damas indias: America's Iconic Body and the Wars of Conquest in the Spanish Comedia.” Bulletin of the Comediantes, vol. 62, no. 1, 2010, pp. 103-122.

Quintero, María Cristina. Gendering the Crown in the Spanish Baroque Comedia. Routledge, 2012.

Rodríguez Cuadros, Evangelina. La técnica del actor español en el Barroco: Hipótesis y documentos. Castalia, 1998.

Rojas Zorrilla, Francisco de. Entre bobos anda el juego. Del rey abajo, ninguno / Entre bobos anda el juego. Edited by Federico Ruiz Morcuende, Espasa-Calpe, 1967.

Ruano de la Haza, José María. La puesta en escena en los teatros comerciales del Siglo de Oro. Castalia, 2000.

Soto, Hernando de. Emblemas moralizadas. Herederos de Juan Íñiguez Lequerica, 1599. Tirso de Molina. La huerta de Juan Fernández. Edited by Berta Pallares, Castalia, 1982.

---. Desde Toledo a Madrid. Edited by Berta Pallares de R. Arias, Castalia, 1999.

Tropé, Hélène. Locura y sociedad en la Valencia de los siglos XV al XVII. Diputació de València, n.d.

Vega, Lope de. Angélica en el Catay. Edited by Marcella Trambaioli. Comedias de Lope de Vega, Parte VIII, 3 vols, Milenio, 2009, III, pp. 1387-1502.

---. El caballero del milagro. Edited by Santiago Restrepo and Ramón Valdés. Comedias de Lope de Vega, Parte XV, 2 vols, Gredos, 2016, II, pp. 973-1145.

---. El castigo sin venganza. Edited by Jonathan Thacker, Manchester UP, 2015. 
---. La discreta enamorada. Arte nuevo de hacer comedias / La discreta enamorada, EspasaCalpe, 1948.

---. Los donaires de Matico. Edited by Marco Presotto. Comedias de Lope de Vega, Parte I, 3 vols, Milenio 1997, I, pp. 115-254.

---. Las famosas asturianas. Edited by Alonso Zamora Vicente, Ayalga, 1982.

---. Las ferias de Madrid. Edited by Donald McGrady, Juan de la Cuesta, 2006.

---. Los locos de Valencia. Edited by Hélène Tropé, Castalia, 2003.

---. La pobreza estimada. Reproduction from the Parte XVIII, Alonso Pérez, 1623, folios 24r51r. Biblioteca Virtual Miguel de Cervantes, www.cervantesvirtual.com/obra-visor/lapobreza-estimada-comedia-famosa--0/html/.

---. La quinta de Florencia. Edited by Debra Collins Ames, Reichenberger, 1995.

---. El ruiseñor de Sevilla. Edited by Eugenio Maggi. Comedias de Lope de Vega, Parte XVII, 2 vols, Milenio, 2018, II, pp. 169-348.

---. La varona castellana. Edited by G. Pontón and G. Serés. Comedias de Lope de Vega, Parte IX, 3 vols, Milenio, 2007, III, pp. 1157-1292.

---. La viuda valenciana. Edited by Teresa Ferrer Valls, Castalia, 2001.

Vélez de Guevara, Luis, La creación del mundo. Edited by William R. Manson and C. George Peale, Juan de la Cuesta, 2018.

---. La mayor desgracia de Carlos Quinto. Edited by William R. Manson and C. George Peale, Juan de la Cuesta, 2002.

---. Las palabras a los reyes y gloria de los Pizarros. Edited by William R. Manson and C. George Peale, Juan de la Cuesta, 2004.

---. Las tres edades del mundo. Reproduction from the Parte treinta y ocho de comedias nuevas escritas por los mejores ingenios de España, Manuel Meléndez, 1672, pp. 
232-276. Biblioteca Virtual Miguel de Cervantes,

www.cervantesvirtual.com/obra/las-tres-edades-del-mundo/.

${ }^{1}$ Like several of the Lope de Vega plays featured in this study, Los locos de Valencia is an early work, dating from the first half of the 1590s. Citations are from Tropé's edition. Dates of plays by Lope, where approximate, are from Morley and Bruerton, unless otherwise indicated.

${ }^{2}$ See Ruano de la Haza esp. 90-93, for the standard functions of costume in the comedia.

${ }^{3}$ Both definitions are taken from the Diccionario de Autoridades. For further detail on types of underclothes worn by women on stage and off, see Argente del Castillo Ocaña, especially 175-76 on "prendas interiores." I am grateful to Esther Fernández for bringing this article to my attention. See also Madroñal's useful glossary of clothing and footwear in the comedia.

${ }^{4}$ Like the Latin nudus, the Spanish term desnudo means, amongst other things, both "naked" and "partially clothed" - the modern Diccionario of the Real Academia Española, reflecting Autoridades of 1732, gives "vestido con ropa escasa o de manera indecente" as its second definition of the adjective.

${ }^{5}$ As Donald McGrady explains in his edition of this play, the character Adrián, who is dressed as Botarga, though not naked, was wearing a tight-fitting costume that would have appeared ridiculous in this case (217). The likely date of composition is McGrady's (7).

${ }^{6}$ The absence of full nakedness and explicit sex scenes on stage in the Golden Age is wellestablished and hardly surprising in the context of Counter-Reformation moral codes. See, for example: Profeti, who writes that, 'no se podrá ahora poner en la escena a un galán abrazando y besando a una dama, o a una dama desnudándose; se podrá a lo mejor sólo contar que se ha entrevisto el pie desnudo de la amada, o a la dama bañándose' (73); MacCurdy, commenting on Rojas Zorrilla's passionate female characters (262); and Rodríguez Cuadros 602. Modernday productions of Golden Age drama are not so constrained and so Erífila, for example, can be much more scantily clad on stage than she would have been in Lope's day: see, for example, the images from Adolfo Marsillach's production of Los locos de Valencia performed at the Teatro de la Comedia in Madrid in 1986, in Diez años de la Compañía Nacional de Teatro Clásico, pp. 16-17 and the 2011 version by the Centro Teatral de la Generalitat in Valencia, directed by Antoni Tordera, available to view at, https://www.youtube.com/watch?v=yG9WoRuFENk.

${ }^{7}$ These references are both taken from Cotarelo, $431 \mathrm{~b}$ and $126 \mathrm{~b}$ respectively. For these and other contemporary authors' concerns about female desnudez, see Esther Fernández

Rodríguez's fine study of eroticism in Golden Age theatre in which she deals with anxiety about states of undress both in the places frequented by actors, e.g. in the vestuario and at rehearsals (chapters 2 and 3 respectively), and on the stage itself (chapter 6).

${ }^{8}$ On the eroticism of the female actors dressed as men, see for example, Ferrer Valls, p. 194 or Carrascón, pp. 130-31.

${ }^{9}$ See Presotto's complementary reading of this scene in his study of costume as a marker of status in a selection of Lope's early plays (380). In his fine examination of identity and metatheatre in Lope's early comedy, Las burlas de amor, Pontón underlines the particular value of clothing for the dramatist at a time when staging was more basic: "En el primer Lope 
es recurso habitual el conceder a la vestimenta (el elemento más conspicuo de una escenografía pobre) un papel simbólico de peso." (92).

${ }^{10}$ Erifila's gradual undressing and the repetition of the unsheathing and sheathing of Leonato's phallic dagger ('Enváinala / Envainarela' at 1. 334, 1. 342 and 1. 350) suggest as much, especially given the comic genre of the play.

${ }^{11}$ Ruano gives examples from comedia stage directions of the kind of costumes which could also be indicative of a character's poverty (90). Presotto discusses including Los locos de Valencia.

12 The date of composition is taken from Daniel Fernández Rodríguez's study of Lope's comedias bizantinas, pp. 311-12.

${ }^{13}$ Quintana does describe Tucapela in Vélez's play as a "nude female welcoming the arrival of Europa" (116) but her state of undress is unclear from the stage directions. Presumably she would be an alluring figure. The dating of the play is taken from the Manson / Peale edition (73).

${ }^{14}$ The term is taken from Tropé's edition of the play, f.n. to 1. 356 (134).

15 The date of the play is taken from Ruiz Morcuende's edition, p. li.

16 'griguiescos' are described as “calzones cerrados en las rodillas” by Vara López, the play's modern editor (164). The suggested date of composition is from her edition.

${ }^{17}$ See Kossoff 385 . He stresses that the bare feet emphasize the sensuality of Casandra which overcomes Federico, though much, as ever, will depend on the performance of this scene.

${ }^{18}$ Cotilla is, according to Autoridades, a "jubón sin mangas hecho de dos telas, embutido con barba de ballena, y pespuntado, sobre el qual se visten las mugeres el jubón o casaca, y trahen ajustado el cuerpo."

${ }^{19}$ The eroticism of the opening of this play has been examined in detail by Esther Fernández Rodríguez who sees Baltasar's examination of Mayor's clothes as a sort of "striptease especial" (117) which sets the erotic tone for the whole play. The estimated date of composition of the play is taken from Pallares's edition.

${ }^{20}$ Rebociño is, according to Autoridades, a "mantilla o toca corta, de que usan las mugeres para cubrir el bozo."

${ }^{21}$ De Armas reminds us that, despite the fact that Spanish painters tended not to produce canvases of nudes in the Golden Age, "[w]ealthy collectors in Spain avidly sought to purchase or copy canvases by Italian masters on mythological subjects" (172-73). Indeed, some images of nudes, like Titian's Adonis and Venus, were well known through prints such as those that Valerio is selling in Lope's risqué comedy La viuda valenciana (11. 887-902). Valerio quips that he himself desires what the painted male figure possesses, i.e. the love of Venus / Leonarda who clings vainly to him as he goes off to hunt: " $¡ O$ Oh quién éste hubiera sido / cuando fue tan regalado!" (11. 893-94). For a broader consideration of Lope's use of painting(s) in his plays and public knowledge of (especially mythological) art works, see Portús Pérez 173-88. And, for a fascinating examination of Lope's probable debt in his mythological plays to Virgil Solis's illustrations for a 1595 edition of Bustamente's translation of Ovid's Metamorphoses, see Boadas, esp. the illustrations on 435 and 442. ${ }^{22}$ Cendal is, according to Autoridades, "tela muy delgada, ligera, sutil y transparente." ${ }^{23}$ One might compare Carlos's words on seeing his Isabel bathing in Mira's Lo que puede una sospecha: "Después que al hermoso adorno / se volvió a restituir, / la vi más hermosa, no, / pero más honesta, sí." Esther Fernández Rodríguez reproduces the whole speech in an appendix to chapter 5 of her monograph $(140-44,143)$.

${ }^{24}$ See Ovid, Meamorphoses, III, 11. 155-85 for the parallels.

25 The description offered by don Juan to Cabellera follows their unclothed nocturnal appearance at the start of act 2, to which allusion has already been made. MacCurdy has studied the strong female characters of Rojas Zorrilla's plays and observes that this dramatist 
"notwithstanding his vaunted feminism, was not above exploiting the female body in order to titillate his audience" (257).

${ }^{26}$ Images of Venus and the faun can be found e.g. as Emblem 7 ("Pulchrum pecunia Faunum") in Hernando de Soto's Emblemas moralizadas from 1599, and in Coreggio's Venus, Cupid and a Satyr (painted c. 1528), now in the Louvre. See Portús Pérez, for another case of a Lope character (Ana of La villana de Getafe) conjuring the image of a "sátiro muy feo / en una tabla pintado" being embraced by an attractive woman, thanks to his rich gifts (176-77). On the nature of Federico's imagination, see Henry and Thacker.

27 The dating of the play in this case is taken from Ferrer's edition.

${ }^{28}$ See de Armas, The Invisible Mistress for a full analysis of the use of the reversal of the Cupid and Psyche story in the Golden Age.

${ }^{29}$ The date of the former play is taken from the edition by Pontón and Serés.

${ }^{30}$ Esther Fernández Rodríguez analyses the eroticism of this play in detail in her monograph (133-39) and it is also briefly explored by Ferrer Valls (201).

${ }^{31}$ This article developed from a paper offered at the conference "Textualizing the Early Modern Body in the Hispanic World" which took place at Princeton University on April 19, 2016. I am grateful to Christina Lee for the invitation to take part. I would also like to express my thanks to the anonymous reviewers of this article who provided very useful suggestions for additional bibliography on this topic. 